\title{
Introduction: The ecology of a river floodplain and the Emiquon preserve
}

\author{
Michael J. Lemke · Jeffery W. Walk • A. Maria Lemke • Richard E. Sparks • \\ K. Douglas Blodgett
}

Received: 10 May 2017/Revised: 26 July 2017 / Accepted: 1 August 2017 / Published online: 13 September 2017

(C) The Author(s) 2017. This article is an open access publication

\begin{abstract}
Scientific study of the Illinois River began before a century of anthropogenic change, thus providing a unique perspective for describing river ecology restoration. In this issue, we explain how systematic monitoring revealed patterns in the restoration of the 2723-ha Emiquon Preserve on the Illinois River. The papers describe (1) how planktonic microorganisms, vegetation, fish, and waterbird communities responded rapidly to flooding of former shallow lakes and wetlands that had been drained and used for dryland agriculture for 83 years; (2) how variation of hydrologic conditions favors biotic community diversity and conditions for carbon sequestration; (3) how fish
\end{abstract}

Guest editors: Michael J. Lemke, A. Maria Lemke \& Jeffery W. Walk / Large-Scale Floodplain Restoration in the Illinois River Valley

M. J. Lemke ( ()

Biology Department, University of Illinois Springfield, MS HSB 223, One University Plaza, Springfield,

IL 62703-5407, USA

e-mail: lemke.michael@uis.edu

J. W. Walk

The Nature Conservancy, 240 SW Jefferson Street, Peoria, IL 61602, USA

e-mail: jwalk@tnc.org

A. M. Lemke · K. D. Blodgett

The Nature Conservancy, Illinois Rivers Office at Emiquon, 11304 N. Prairie Road, Lewistown, IL 61542, USA

e-mail: mlemke@tnc.org populations imposed a trophic cascade and affected diversity, yet may not help control some undesirable fish species; and (4) how simulation models are useful in planning, but that restoration practice and management decisions must adapt to present conditions, involve trade-offs, and are influenced by competing stakeholder interests. Unsurprisingly, water level management remains the most important factor in the restoration ecology of floodplains; however, the establishment of a river-floodplain connection should be managed to achieve a balance between establishing hydrology that mimics natural flood pulses while minimizing contemporary threats, including excessive nutrient and sediment loads and invasive species.

Keywords River - Restoration ecology - Ecological attributes $\cdot$ Shallow lake $\cdot$ Flood pulse

K. D. Blodgett

e-mail: dblodgett@tnc.org

R. E. Sparks

Illinois Natural History Survey, Champaign, IL 61820,

USA

e-mail: rsparks@illinois.edu

Present Address:

R. E. Sparks

P.O. Box 176, Elsah, IL 62028-0176, USA 


\section{Introduction}

Alterations to the Illinois River and its floodplain and watershed began relatively late (1800s) and occurred rapidly when compared to similar modifications in large rivers. One advantage of the relatively recent changes to the Illinois River was the establishment of the Illinois Natural History Survey (INHS) field station along the middle reach of the river where the Emiquon Preserve exists today (Fig. 1). Under the direction of Stephen A. Forbes, a team of scientists conducted systematic field studies of hydrology, chemistry, and biology that documented the productivity of the Illinois River prior to significant alterations for navigation, agriculture, and urban development (Starrett, 1972; Schneider, 2000). Such extensive historic scientific documentation (e.g., Forbes, 1876, 1888; Hart, 1896; Kofoid, 1903; Forbes, 1907; Forbes \& Richardson, 1908) exists for few other rivers worldwide

Commercial development and engineering of the Illinois River was swift; however, so was the rise of the U.S. conservation movement in the 1920 s and the subsequent environmental movement in the late 1960s. Conservation policies restored $8 \%$ of the floodplain wetlands along the Illinois River that had been leveed and drained, and preserved over $90 \%$ of the original floodplain in the northern part of the Upper Mississippi River as U.S. National Fish and Wildlife Refuges (Scarpino, 1985; Thompson, 2002). Environmental policies vastly improved water quality in both rivers, required federal agencies to assess environmental impacts of river development projects, and led to a cooperative federal-state program (the Upper Mississippi River Restoration Program, UMRRP) that has monitored natural resources and restored degraded habitats in both rivers for over 30 years (USACE, 2016). The INHS has continued to study the river during these periods of change, participating in the UMRRP and documenting the recovery of fish and mussel populations (Sietman et al., 2001; McClelland et al., 2012).

The Nature Conservancy (from here, "Conservancy") has played a coordinating role in recent recovery efforts by working with users of the Illinois River, including commercial interests, non-governmental organizations, and local, state, and federal government agencies, to develop a comprehensive restoration plan (Illinois River Strategy Team, 1997;
USACE, 2006). In addition, the Conservancy developed site conservation plans and demonstration projects in tributary watersheds (Lemke et al., 2010; Lemke et al., 2011) and in the river floodplain that includes the Emiquon Floodplain Restoration Project (TNC, 1998), which is the focus of this Special Issue.

After a decade of restoration at the Emiquon Preserve, considerable progress has been made toward the primary objective of the project to restore the natural hydrology and ecological processes that sustain the aquatic and terrestrial communities associated with the river-floodplain system. Additional goals included flood attenuation, sediment capture, nutrient processing, and improved governance for coordinated management of the system (TNC, 1998, 2000) that would provide ecological, social, and economic benefits within the Illinois River system and would contribute to better resource quality for the Mississippi River (Reuter et al., 2005).

Several additional aspects of the Emiquon Preserve restoration case study are noteworthy. First, there was a coordinated planning process prior to restoration among external experts and stakeholders that resulted in a guidance framework to assess restoration status over the early restoration period (Lemke et al., 2017a, b, c, d). Secondly, the restoration and monitoring were designed to contribute to better documentation of the feasibility and sustainability of ecological restoration in highly altered floodplain-river systems (Suding et al, 2004; Choi et al., 2008; Hobbs \& Cramer, 2008; Jackson \& Pringle, 2010). In this Special Issue, we offer a perspective that we hope will contribute to restoration and conservation programs of large river ecosystems worldwide by providing (1) an overview of the scientific and historical context of the river and region; (2) a description of restoration progress at the Emiquon Preserve; and (3) an overview of the significance this collection of studies has for large river restoration ecology.

\section{Part 1: The Scientific and Historical Context of the Illinois River and Region}

The complex history of change to the Illinois River can be summarized with key events in science and management (Fig. 1) within the context of three descriptive periods: (1) minor human disturbance, 


\section{Events Affecting Resource Management \& Policy}

\section{Events in Science and Aquatic Ecology}

1850

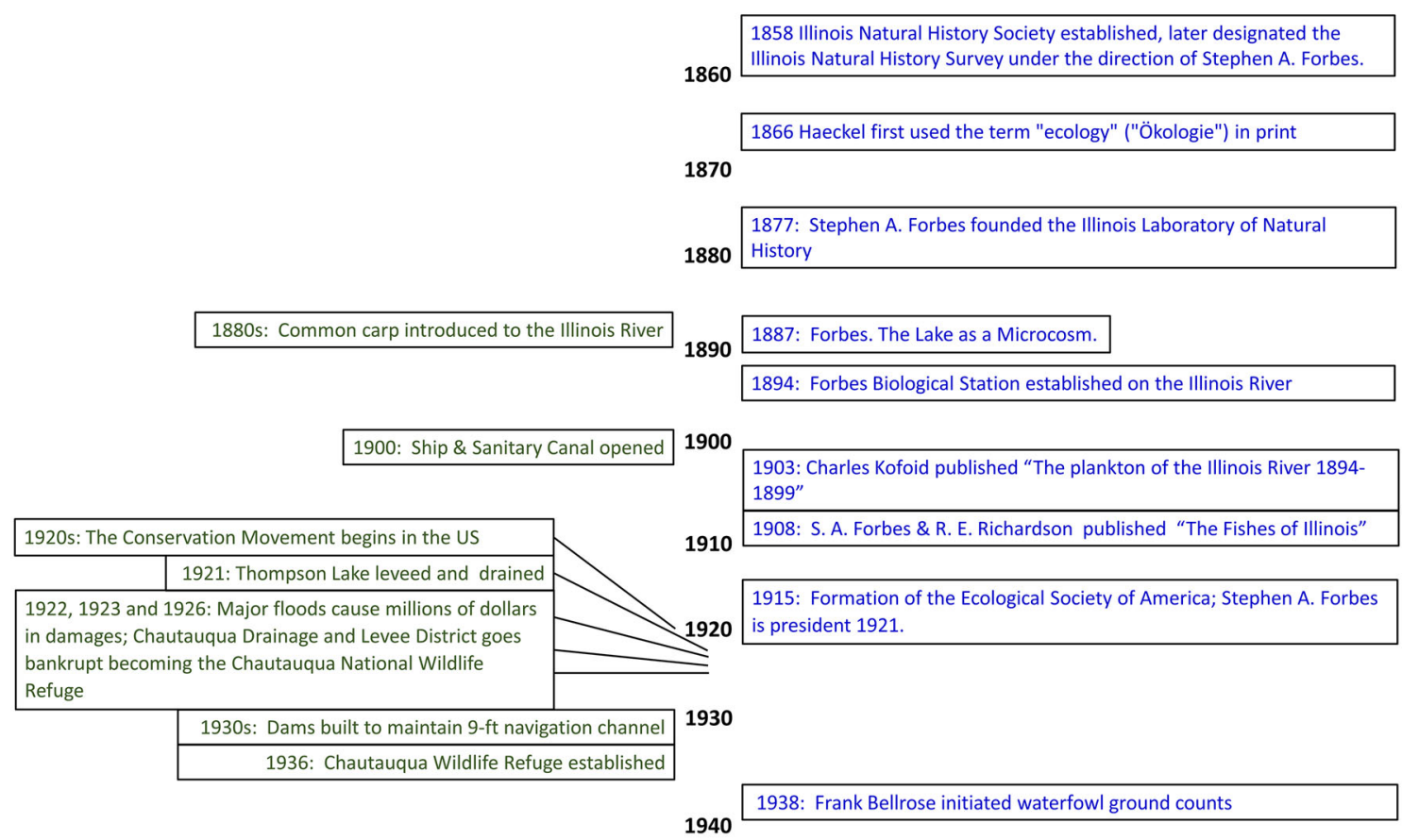

1950: Jenkins et al. Survey and Report on Potential Conservation Areas Along the Illinois River from Hennepin to Grafton
1970-1974: National Environmental Policy Act (NEPA), Clean Water Act, First Earth Day, Endangered Species Act, Safe Drinking Water Act

\section{0}

1960

1970

1980

\begin{tabular}{|l|l|}
\hline $\begin{array}{l}1993 \text { The Great Midwestern } \\
\text { US Flood led to new } \\
\text { recommendations for } \\
\text { floodplain management }\end{array}$ & \\
\cline { 2 - 2 } & \\
\cline { 2 - 2 } $\begin{array}{l}\text { 1994: Illinois River closed to } \\
\text { commercial mussel collection }\end{array}$ & 1990s: Asian carp recorded in IL River \\
\cline { 2 - 2 } 2000
\end{tabular}

1956: Starrett began the annual surveys of the fish populations of the Illinois River that continue today

1959: Jackson \& Starrett. Turbidity and sedimentation at Lake Chautauqua, Illinois.

1966: Mills, Starrett \& Bellrose. Man's Effect on the Fish and Wildlife of the Illinois River

1971: Starrett. A Survey of the Mussels of the Illinois River: a Polluted Stream

1980-1986: US National Science Foundation: Large River Long Term Ecological Research (LTER)

1986-present: USGS Long Term Resource Monitoring Program (LTRMP)

1989: Junk et al. Floodpulse concept

2007: On ground restoration of Emiquon Preserve Begins

2012: Emiquon "Wetland of International Importance" by Ramsar Convention

2013 (25 April): Highest flood recorded

in 150 years of stage measurements by

various agencies near Emiquon; 2015:

Second highest flood of record

\begin{tabular}{|l|}
\hline \hline $\begin{array}{l}2016 \text { (July) Emiquon levee gate } \\
\text { completed for managed } \\
\text { connection to the river }\end{array}$ \\
\hline
\end{tabular}

2007: $1^{\text {st }}$ Annual Emiquon Science Conference

2010

2017: Special Issue on Illinois River floodplains published in Hydrobiologia

Fig. 1 Select relevant scientific landmarks (right) and historical events marking land use (left) in the study and development of Thompson Lake, IL 
(2) human development and major impacts, and (3) recovery and restoration.

Period 1 (prehistoric-1900): Period of minor human disturbance

The Illinois River begins at the junction of the Kankakee and Des Plaines rivers in northern Illinois, and drains $73,038 \mathrm{~km}^{2}$ as it flows $439 \mathrm{~km}$ to the Mississippi River (Starrett, 1972). Its broad floodplain and seasonal flood pulse lent it similar qualities to large lowland rivers of the world and supported prehistoric populations of Native Americans primarily between 800 and 1400 A.D. (Esarey, 1993). Impacts (e.g., harvesting of natural resources for tools, food, fuel, and construction; gardening and farming; and intentional burning of prairies and some woodlands) of these early civilizations on the river system were not thought to be extensive based on archeological records that document their activities (Wiant \& Berkson, 2004).

There were about 40,000 people in the southern part of Illinois in 1800 when it became a state (Buck, 1967); yet by 1840 , about 190,000 people inhabited the Illinois River Basin south of Chicago (Starrett, 1972). A canal, completed in 1848 and used until 1910, connected the south-flowing Illinois River to Lake Michigan and apparently had little effect on river ecology as indicated by thriving mussel populations (Calkins, 1874; Starrett, 1971).

During that time, the science of ecology was founded and several important ecological studies on the Illinois River laid the foundation of the aquatic ecosystem concept (Cocker, 2001). While serving as State Entomologist of Illinois and Professor of Zoology and Entomology at Illinois State University, Stephen A. Forbes delivered a talk to the 1887 meeting of the Peoria Scientific Association entitled "The Lake as a Microcosm" that was later published (Forbes, 1887) and widely cited as a classic paper in ecology (Real \& Brown, 1991). Forbes explained how Illinois lakes were either watershed lakes or "fluviatile lakes... situated in the river bottoms and connected with the adjacent streams by periodical overflows," and the importance of these lakes as "reservoirs of life." Forbes was named director of the State Laboratory of Natural History in 1877 and became the first chief of the INHS in 1917 (Havera \& Roat, 2003) marking a period of nearly unprecedented study of the river. Scientific studies of riverine backwater habitats, which included Thompson and Flag Lakes of the present-day Emiquon Preserve (Fig. 2), described changes in hydrology, plankton (Hempel, 1898; Kofoid, 1903, 1908), mussels (Baker, 1906), aquatic insects (Hart, 1896), fishes, and fish production (Craig, 1889; Forbes and Richardson, 1908). These studies documented the Illinois River and its floodplain as a high-functioning and largely intact system (Havera \& Roat, 2003).

Period 2 (1901-1971): Human development and major impacts to the Illinois River

Pioneering research that focused on the more natural river system shifted to studies of a river under development and impacted by changing land uses. Construction of the Chicago Sanitary and Ship Canal was the largest earth-moving operation in North America in the early twentieth century, designed to divert polluted water away from Chicago's drinking water sources in Lake Michigan into the Illinois River (Hill, 2000, p. 127). It opened in 1900 reversing the flow of the South Branch of the Chicago River from north into Lake Michigan to flowing south ultimately into the Illinois River, transporting raw sewage and storm water away from Chicago (Cain, 1978; Changnon \& Changnon, 1996). Pollution in the upper reach resulted in extirpation of all mussels by 1912 (Forbes \& Richardson, 1913) and fishes by the late 1920s (Thompson, 1928). Pollution advanced downstream into the lower reaches of the river resulting in the loss of some invertebrate species (Richardson, 1928) and the replacement of clean water species (e.g., mayflies and a variety of snails) with pollution-tolerant forms (e.g., tubificid worms and midge larvae).

Water diversion from Lake Michigan increased the average base water levels in the Illinois by $0.9 \mathrm{~m}$ near Emiquon from 1900 to 1909 (Forbes \& Richardson, 1919). Initially, higher water levels increased aquatic habitat, but what appeared as an advantage soon contributed to long-term degradation (Bellrose et al., 1983). Expanded water surface areas increased wind fetch and wave action that eroded shorelines, uprooted aquatic plants, and suspended soft fluvial sediments (Sparks et al., 1990). Water-intolerant tree species perished essentially removing windbreaks on islands and along the river banks. Water diversion from Lake Michigan was eventually reduced by decrees from the 


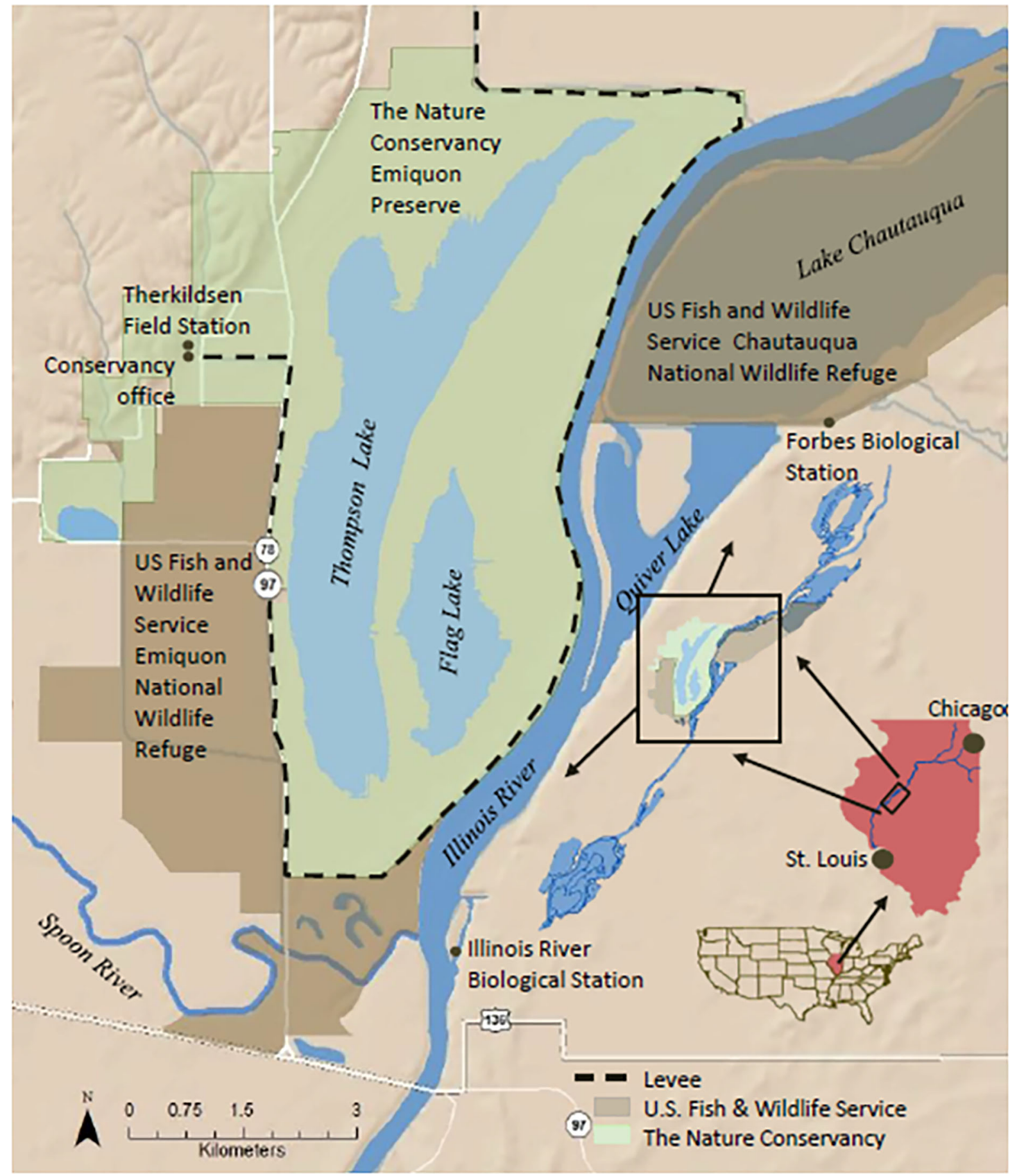

Fig. 2 Location of the Emiquon Preserve along the Illinois River with nearby conservation lands and science facilities

U.S. Supreme Court, yet base-flow water levels in the river remained elevated from pre-development levels as a series of mainstem dams were completed in the 1930s to maintain depth for navigation (Starrett,
1972). These dams permanently elevated low water levels upriver of the dams that depleted the river system of the natural low water stages (Lian et al., 2012), thereby compromising such ecosystem services 
as sediment compaction, moist soil revegetation, and mineral processing.

From 1890 to 1924, widespread levee construction and drainage of river floodplain habitats (Thompson, 2002) contributed to a channelized river mainstem, reduced flood pulses to the floodplain, and nearly half of the floodplain, including Thompson and Flag Lakes, being converted to agricultural production (Havera et al., 2003; Fig. 3). Jenkins et al. (1950) reported that levee construction resulted in flood crests three meters higher in 1943 than occurred during pre-construction floods of 1904.

Subsoil drainage associated with agriculture and channelization of the tributaries increased erosion and accelerated the delivery of water and sediment to the river. Sedimentation rates were as high as $78 \mathrm{~mm}$ /year in floodplain lakes that were still connected to the river, resulting in a loss of approximately $75 \%$ of backwater lake volume by the late twentieth century (Bhowmik \& Demissie, 1989; Demissie et al., 1992). Loss of hydraulic storage, in conjunction with increased frequencies of high-precipitation events, and enhanced drainage from the watershed (Jha et al., 2004; Tomer \& Schilling, 2009; Kunkel et al., 2013) contributed to increased flood events and an erratic river hydrograph (Figs. 4A, B). Such hydrologic changes lie at the heart of large river ecosystem degradation.

Large floods in 1943 and 1944 reduced vegetation and dispersed sediments to the river mainstem and floodplain lakes. Pollution in the upper river created and perpetuated an area devoid of aquatic life. The lakes and backwaters of the middle river that Kofoid (1903) had described as aquatic gardens early in the century had become turbid, plantless "deserts" by the 1950s (Bellrose et al., 1979). Loss of the onceabundant fingernail clams (Sphaeriidae), snails (Gastropoda), and burrowing mayflies (Hexagenia spp.) led to a decline of fish and waterfowl populations (Mills et al., 1966). Subsequent sediment bioassays revealed that toxic, unionized ammonia in the nitrogen-enriched sediments may have caused the original die-offs of burrowing macroinvertebrates and accounted for their failure to recolonize (Sparks et al., 1993). Similarly, reduced commercial fish body conditions were recorded as fish harvests declined and diving ducks virtually stopped using the Illinois River as a migration route (Mills et al., 1966).
Period 3 (1972-present): Recovery

and Restoration

The passage of the Clean Water Act in 1972 signaled the beginning of improved water quality owing to upgraded wastewater treatment methods. Even so, it would take decades for fish (Lerczak \& Sparks, 1995; Pegg \& McClelland, 2004) and mussels (Sietman et al., 2001) to recover. The twentieth century closed with an articulation of a significant river ecology theory that incorporated flood pulse patterns observed from the Illinois River: the "Flood pulse Concept" (Junk et al., 1989) and "The Flood pulse Advantage" (Bayley, 1991) emphasized the importance of the flood pulse in large river ecology and how it is essential for high system-level biological productivity.

By 1992, the Illinois River system was designated as having high potential for restoring ecosystem function of the river and its floodplain (National Research Council, 1992; Upper Mississippi River Conservation Committee, 2000; U.S. Army Corps of Engineers, 2006). These assessments for restoration were based on the facts that the Illinois River had low navigation dams and that over $50 \%$ of the floodplain remained unleveed. Initiation of habitat and floodplain restoration of the river system would need to take into consideration all of the system-level impacts that contributed to degradation of the system over time. These impacts included (1) leveed floodplains, (2) agriculture and urbanization, (3) increased flood flashiness, (4) increased river flows from diversion, (5) unnaturally high river water levels, (6) invasive species, and (7) high loads of sediment, contaminants, and nutrients (Jackson \& Pringle, 2010; Guida et al., 2016; Sparks et al., 2016; Lemke et al. 2017a). The story of the Emiquon Preserve began in 2000 .

\section{Part 2: Acquisition, planning, and restoration of the Emiquon preserve: large-scale restoration ecology comes to the Illinois river}

Opportunity, need, and providence can work in concert to bring about change, and such was the case in the area north of the confluence of the Illinois and Spoon Rivers today known as the Emiquon Preserve (Fig. 2). The relevant aspects of the Emiquon 


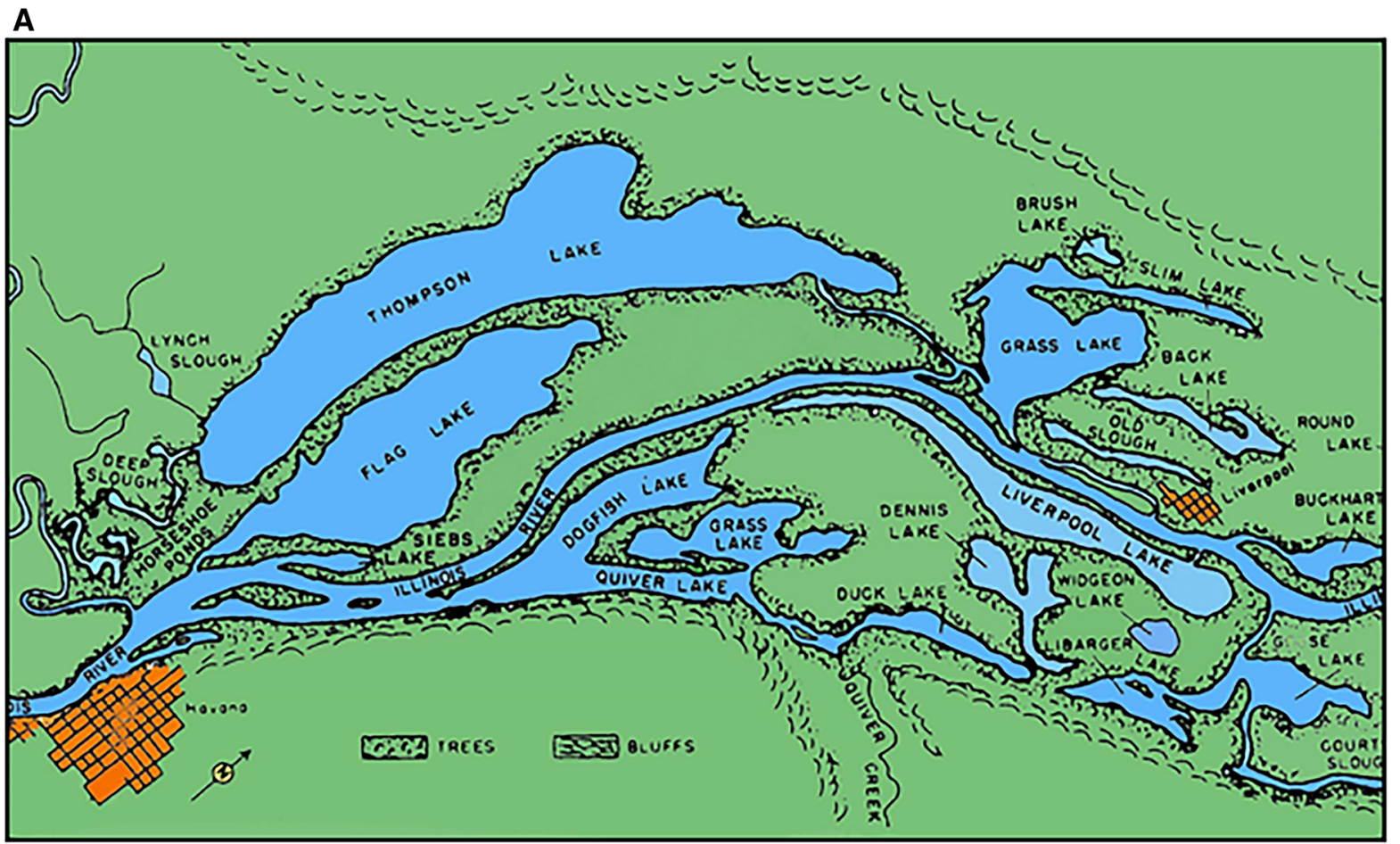

B

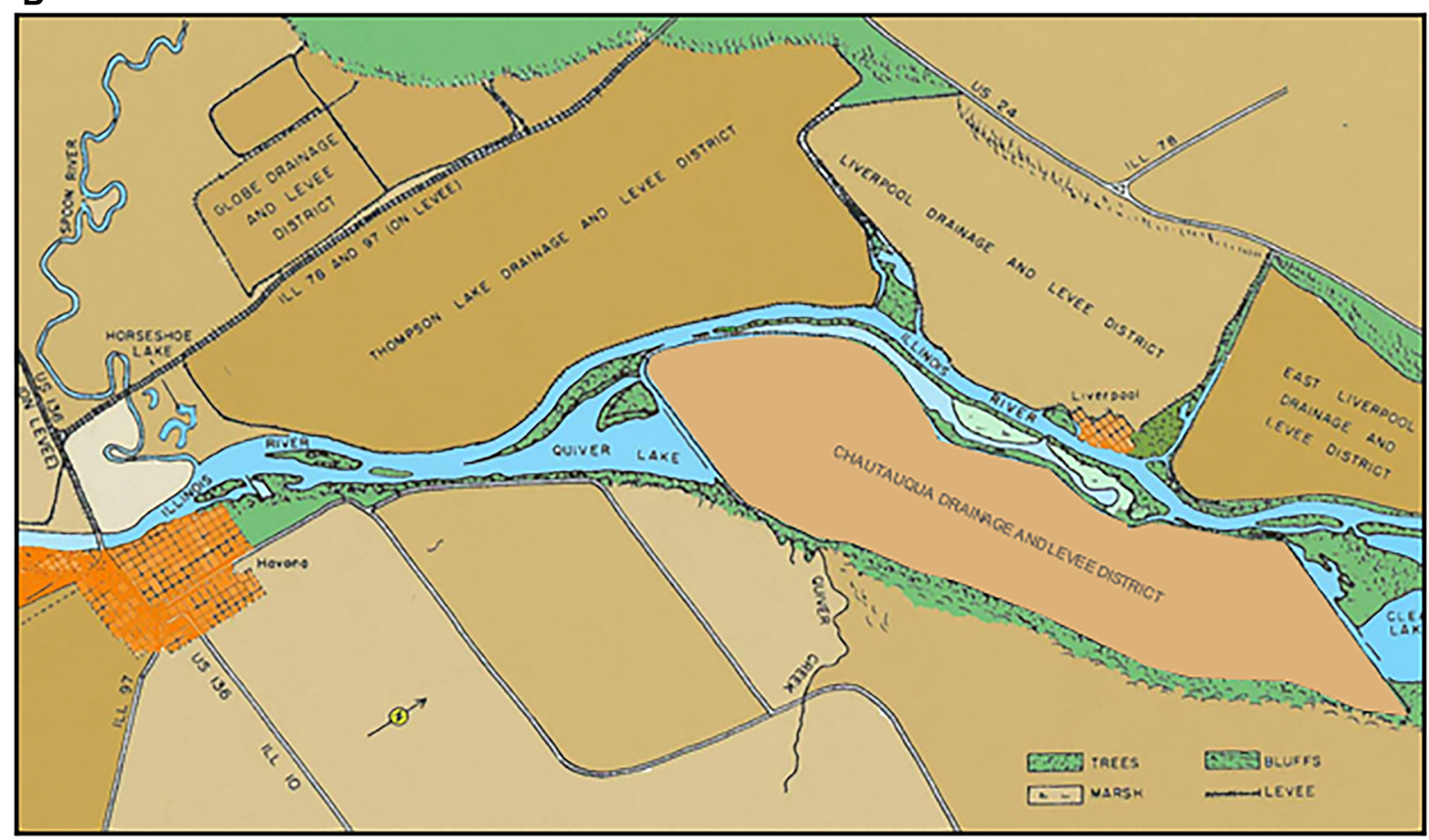

Fig. 3 A Thompson and Flag Lakes, the site of the future Emiquon Preserve, as part of the Illinois River System prior to circa 1912. B The same area after levee construction, drainage, and conversion to agriculture circa 1925. (After Mills et al., 1966, Fig. 2) 


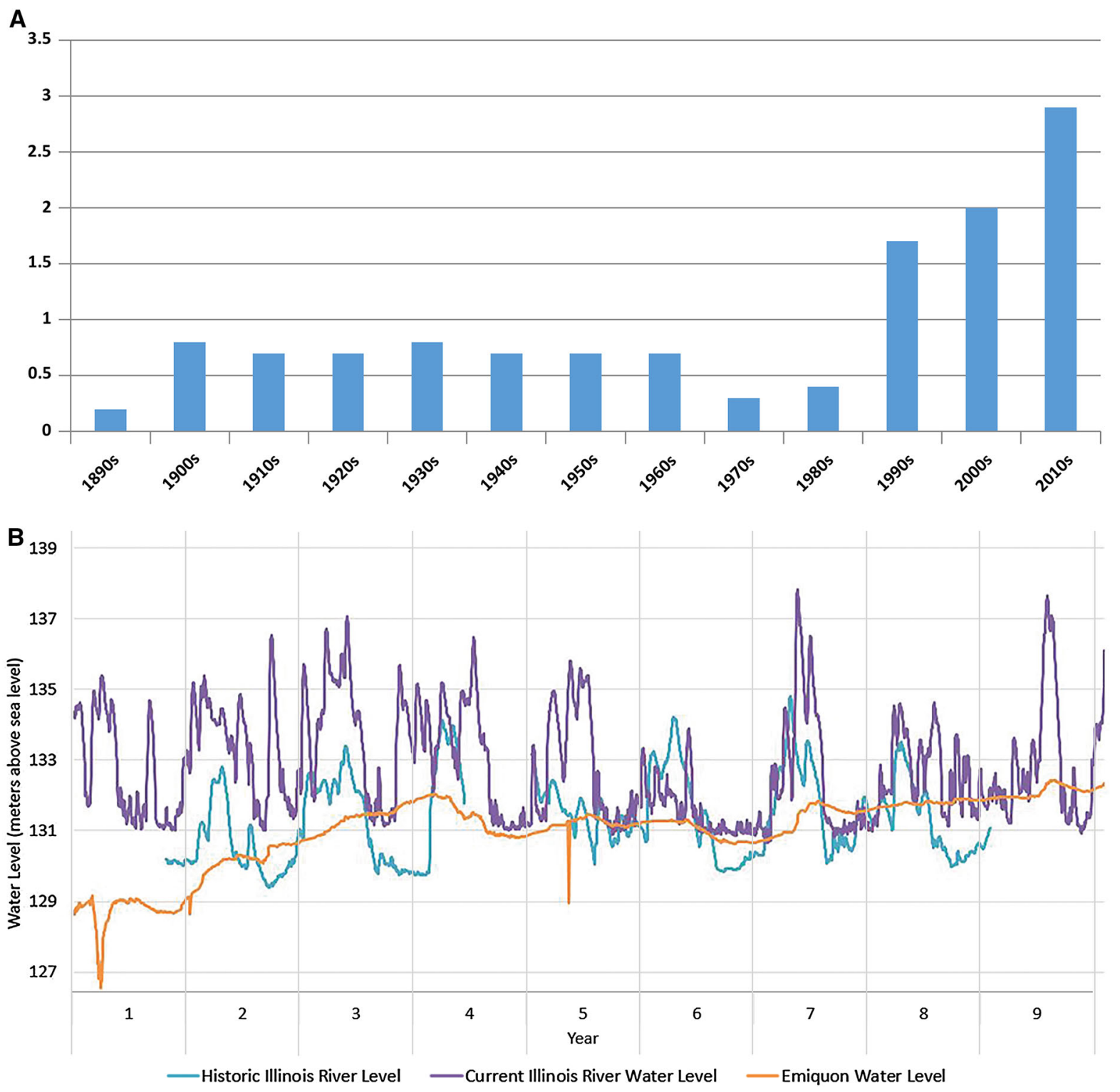

Fig. 4 A Annual frequency of the Illinois River reaching flood stage at Havana, Illinois, near the Emiquon Preserve, by decade 1890 s to the present. Only floods separated by $>30$ days are included to differentiate distinct flood events. Observations by US Army Corps of Engineers accessed at http://water.weather. gov/ahps $2 /$ hydrograph.php?wfo=ilx \&gage=HAVI2 .

Preserve's restoration to this Special Issue include the role of science in restoration and the Conservancy's approach to management. Given that restoration requires planning and long-term commitments, a brief description of future plans is also described.
B Hydrograph of the Illinois River near present-day Emiquon Preserve, depicting late-nineteenth-century flood pulse (spring flood, low and stable summer water levels; blue line), erratic present day fluctuations (purple line), and water level within the Emiquon Preserve (brown line)

Acquisition and partnerships

The Emiquon Preserve was established in 2000 when the Conservancy acquired most of the Thompson Drainage and Levee District (Fulton County, IL; 
centroid at: N4471044, E749023 UTM Z15). Over $90 \%$ of the 2,723-ha Emiquon Preserve is in the floodplain west of the river. Immediately adjacent are the 1,052-ha Emiquon National Wildlife Refuge and 1,817-ha Chautauqua National Wildlife Refuge. The Emiquon complex, comprising the Emiquon Preserve and the U.S. Fish and Wildlife Service's Emiquon and Chautauqua National Wildlife Refuges, was recognized in 2012 as a Ramsar Wetland of International Importance (Ramsar, 2014). Together, these three properties create a 5,592-ha complex of rivers, sloughs, flood-pulsed backwater areas, bottomland hardwood forests, prairies, and bluffs that closely represent the historical diversity of the area and establish an 8.5-km-wide corridor across the floodplain and extends $13.5 \mathrm{~km}$ in length downstream.

Scientific studies of the Illinois River system continue to play a significant role in planning and documenting the outcome of restoration at the Emiquon Preserve. Over 180 scientific research permits were issued by the Conservancy between 2007 and 2016. Nearby facilities each serve a role in the scientific contribution to restoration and management efforts and include (1) INHS Forbes Biological Station whose specific focus is on the ecology and management of wetlands, waterfowl, and other waterbirds; (2) INHS Illinois River Biological Station, which is part of the Long Term Resource Monitoring element of the UMRRP, and whose monitoring includes fish, vegetation, and invasive species; (3) Illinois State Museum at Dickson Mounds, an on-site museum whose ongoing archeological research and displays document how the abundant natural resources of the Illinois River and its floodplains have supported human communities for at least 12,000 years (Wiant \& Berkson, 2004); and (4) University of Illinois Springfield Therkildsen Field Station that supports education and exploration of the Emiquon Preserve and has been instrumental in orchestrating science information exchange through annual science meetings since 2007 (Fig. 2).

\section{Planning}

In 2001 and 2004, the Conservancy convened a 50-member Emiquon Science Advisory Council (hereafter, Council) of scientists, resource managers, and private wetland restoration practitioners to assist in development of a plan for restoration and long-term management. The Council emphasized the importance of natural variation in the hydrologic regime and periodic connections between rivers and their floodplains to maintain biological productivity and diversity. The Council also recognized the potential negative effects of reconnecting to a highly altered system with an elevated hydrograph (e.g., Jackson \& Pringle, 2010).

The Council advised simulation models be developed for alternative reconnection scenarios between the river and Preserve. These models showed that hydrologic variation associated with reconnection could be beneficial and that reconnection would need to be managed to limit deleterious effects (Demissie et al., 2005). Using a water control structure and pumps, a flood regime could be established to provide drawdown and sediment compaction periods that would have periodically occurred in Thompson and Flag Lakes prior to disconnection from the Illinois River (Bellrose et al., 1979; Havera \& Roat, 2003). Alternating seasonally timed periods of drawdown with flood events could enhance the establishment of desirable plant and animal communities (van der Valk \& Davis, 1978) and help manage sediment deposition to maintain water depths and water quality (Sparks, 1995).

\section{Restoration}

Among the myriad of considerations that go into a long-term, large-scale restoration, hydrology, biota, and outreach to stakeholders are aspects that were prominent in the Emiquon restoration and are relevant to other large river restoration efforts. Site hydrology of the Emiquon Preserve changed when ecological restoration began in 2007. Drainage of the site through water pumping was discontinued and water levels rose primarily due to direct precipitation. In 2008 and 2009, exceptionally heavy rainfall rapidly increased water volume and surface area within the Preserve (Angel, 2010; Fig. 4B) to the point that the separate lake basins of Thompson and Flag Lakes formed a single 2,000-ha water body. Except for limited pumping in 2008 and 2010 and brief periods of river water inundation during flood events in 2013, 2015, and 2016, water levels have been stable since 2010 . Evaporation during a moderate summer drought in 2012 resulted in a 0.6-m drop in water level that was followed by a 1.2-m rise the spring of 2013 when 
levees were over-topped for six days during record flooding on the Illinois River. By contrast, the level of the Illinois River varied more than $7 \mathrm{~m}$ during this same time (USACOE River Gages.com-Havana gage), and the historic hydrograph suggests that prealteration river levels rose and fell 3.0-4.5 $\mathrm{m}$ from the average spring peak to the average summer low level (Fig. 4B). Construction of a water management system was completed in 2016 and consists of two $4.6-\mathrm{m}^{2}$ gates and two $1.9-\mathrm{m}^{3} / \mathrm{s}$ pumps that will allow controlled movement of water between the Emiquon Preserve and the Illinois River (Fig. 5A, B).

Restoration of the biological communities was accomplished by plantings, fish stocking, natural regeneration, and recolonization. While aquatic vegetation was allowed to re-establish from existing seed banks, dispersion from drainage ditches, or by seed dispersal, tallgrass prairie areas were established by seeding and bottomland forest through the planting of about 180,000 sapling trees of 10 hardwood species. More than 1,800 ha of row-crop fields with deep ditches and subsurface drain tiles were transformed into marsh and shallow lake habitats with submerged and floating-leaf aquatic vegetation, persistent emergent vegetation, and open water (Hine et al., 2014). To establish the fish community, the Illinois Department of Natural Resources and the Conservancy developed a cooperative fisheries management agreement for the Emiquon Preserve. Existing fish populations in the drainage ditches (e.g., common carp; Cyprinus carpio) were drastically reduced, then stocking of about 435,000 young-of-year and adults of 31 native species, and 1.2 million larval largemouth bass (Micropterus salmoides; VanMiddlesworth et al., 2014), followed.

Outreach and public use of the Emiquon Preserve are also key elements of the restoration project. A public visitor use area with educational and interpretive facilities was constructed by the Conservancy. In addition, public access for canoeing, bird watching, hunting, and fishing is allowed resulting in 27,000 visitors in 2015 (about 1600 permits for boating and fishing, 450 hunting permits, and 1600 people attending programs and tours).

Significant strides toward achieving the Preserve's goals can be observed by the return of species richness and abundance comparable to historical references. However, success for lentic aquatic systems in a prairie landscape may be short lived without the dynamic, flood-pulsed river hydrology as the driving mechanism for large river restoration. Restoration ecology theory forecasts that the future is far from apparent even in systems simpler than those driven by disturbances, including flooding. For instance, Suding (2011) explains several possible restoration trajectories that may diverge from targeted outcomes and Matthews and Spyreas (2010) showed early trajectories of restored wetlands diverged toward different higher-integrity states, but over longer periods converged on degraded states.

Three potential future conditions for the Emiquon Preserve have analogs within the Illinois River system: reservoirs, moist soil management areas, and extant backwaters with unmanaged connectivity with the river. If the Emiquon Preserve were to be kept in isolation with a relatively flat hydrograph, the wetland is likely to degrade (van der Valk \& Davis, 1978; Hine et al., 2016) and take on the function and composition of a reservoir similar to sites managed for sport fisheries. This management model would provide little or no persistent emergent, hemi-marsh, or submersed aquatic-floating-leafed vegetation habitats that benefit native fishes and other floodplain biota. A second scenario seen at regional sites isolated from the river is the complete or nearly complete annual summer drawdown of water for moist soil plant production to provide habitat for migratory waterfowl (e.g., Bowyer et al., 2005; Stafford et al., 2010). Managing for moist soil areas helps simulate the advantages of a changing hydrograph. However, without hydrologic connectivity, these sites would contribute little to the aquatic productivity and diversity of the river ecosystem. The third option for future conditions listed here would be to simply open the levees to the river and create an unmanaged connection to Emiquon. In this scenario, the Preserve would eventually take on the characteristics of other extant connected backwater lakes that have become loaded with flocculent sediment, fail to support rooted aquatic vegetation, and are dominated by non-native fishes. Sedimentation rates would be relatively slow because of the large volume of Emiquon in relation to the openings, which would most likely be relatively small initially because of the cost of excavation (Demissie et al., 1992).

The Conservancy's working hypothesis for the Emiquon restoration is that a managed reconnection will facilitate the reestablishment of a dynamic hydrology that mimics the historic flood pulse (Reuter 

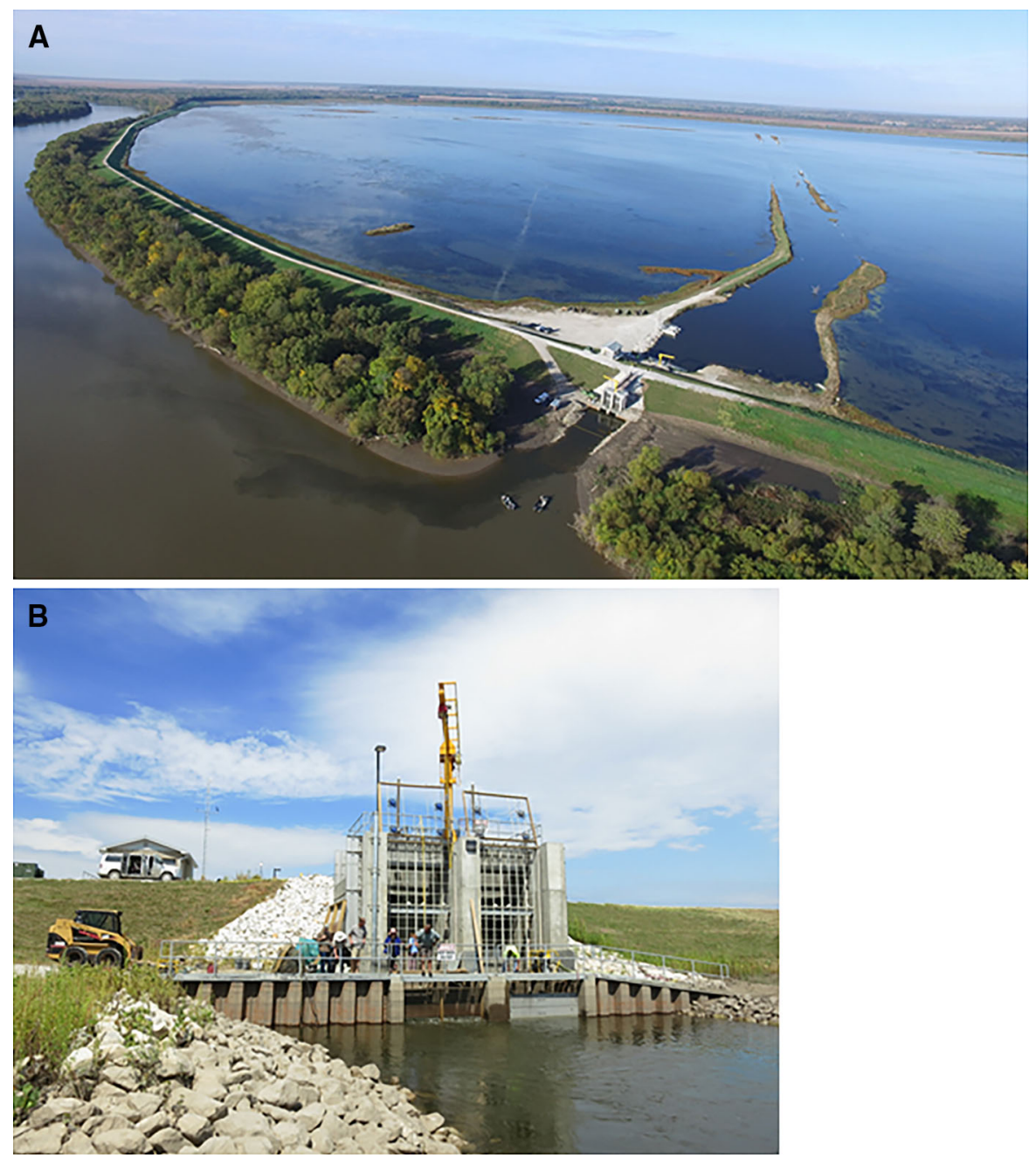

Fig. 5 A Emiquon Preserve (right) and Illinois River (left) on October 19, 2016. Clear water was being discharged from Emiquon into the Illinois River. Anglers in two boats are fishing in the discharge. The former agricultural drainage ditch, lined with trees and shrubs, extends into the distance at the right (Photo: D. Blodgett). B Looking from the Illinois River toward the gate structure in the Emiquon levee. The yellow crane on top of the structure is used to lift nets, other sampling devices, screens, and metal stop "logs" in and out of the gates. Stop logs

et al., 2005). The importance of the timing, magnitude, and duration of the river flood pulse to the ecology of the river system cannot be overstated; it is perhaps the most important driver of high biological diversity even to the point of controlling invasive species. Thus, by managing the timing, direction, and quantity of water movement between the Preserve and the Illinois River, diversity and integrity of the vegetation communities are in place in the gate on the right, and screen is in place in the left gate, which is discharging water from Emiquon into the Illinois River. On top of the structure are two frames with underwater speakers that are used to test the effectiveness of sound in repelling Asian carps. The structure on top of the levee behind the white van houses data loggers. A mast with meteorological sensors is to the right of the instrument house (Photo: R. Sparks)

will be maintained. Supporting a diverse natural flora should help suppress invasive species through biotic resistance, though active control will likely be necessary periodically. A controlled river connection can allow water to pass to and from the Preserve at opportune times for river water height, yet when sediment load is lower, thus limiting sediment deposition (Fig. 5A, B). 


\section{Part 3: Scientific perspectives of the large-scale floodplain restoration in the Illinois river valley}

This special issue for Hydrobiologia is a collection of papers authored by the scientists and managers who have been studying the Emiquon Preserve restoration project since its inception. It represents work that paints a comprehensive scientific picture of restoration with an emphasis in this issue on shallow lakes and their associated wetland habitat along the Illinois River.

\section{Overview paper}

Incorporating the insights of the Council with a framework developed by Parrish et al. (2003), the Conservancy identified conservation targets for the Emiquon Preserve restoration. These targets were framed by key ecological attributes (KEAs) with measurable indicators used to assess ecosystem status (TNC, 2006). In this issue, Lemke et al. (2017a, b, c, d) report how the application of the KEA framework during the initial eight years of restoration directed a systematic monitoring program that provided annual data on the status of conservation targets. Continued review and modification of the KEA model in conjunction with strategic monitoring and a managed reconnection to the river will provide relevant information to guide future management decisions and testable hypotheses to reduce potential threats and achieve restoration goals.

\section{Community-level papers}

A range of ecological responses to restoration have been closely monitored that include microorganisms (Lemke et al., 2017b), vegetation (Hine et al., 2016), fish (Van Middlesworth et al., 2016a, b), and waterbirds (Hagy et al., 2016a, b), making the Emiquon Preserve among the most intensively studied floodplain restorations in the world.

Lemke et al. (2017b) recognized that large river system conditions may change rapidly, and characterized microbial communities whose member populations consist of a mix of rapid and slow responders. Even in the first full year of restoration in 2008, bacterioplankton, protozoans, phytoplankton, and zooplankton showed seasonal changes that were very different in Thompson Lake than those in a nearby reference lake (Lake Chautauqua). Bacteria, phytoplankton, and zooplankton in the newly restored lake appeared to respond quickly to events such as nutrient surges and cyanobacterial blooms, whereas ciliate richness and abundances showed less change through time indicating more of a buffered response between nutrients and predation. Indicator taxa mapped by Lemke et al. (2017b) serve as a reference for subsequent restoration efforts.

Unlike many floodplain lakes along the Illinois River, Thompson and Flag Lakes had rapid wetland vegetation response because the lakes were devoid of significant sedimentation and maintained moderate water depths (Hine et al., 2016). Hine et al. (2016) report that natural regeneration accounted for an eightfold expansion of vegetation from 2007 to 2013 and that the dominant vegetation in the wetland habitat consisted of floating-leaved and submersed aquatic vegetation (about 44\%) and persistent emergent vegetation $(21 \%)$, habitat types historically abundant in Illinois River backwater lakes yet largely absent from contemporary backwater lakes.

Fish communities also responded positively to reflooding of the Emiquon Preserve lake basins (VanMiddlesworth et al., 2016a). Fish species richness increased the first five years of restoration at the Emiquon Preserve and approximately $66 \%$ of the original 32 species that were stocked in 2008 were collected during monitoring. Inability to collect the remaining 33\% could have been due to many factors, including the sequence in which species were introduced to the growing assemblage, small number of individuals stocked for many species, and intentionally high stocking of piscivorous fishes. Van Middlesworth et al. (2016a) addressed the feasibility of biomanipulation to suppress invasive species by increasing largemouth bass predation. VanMiddlesworth et al. (2016b) explored the diets of several piscivorous fishes at the Emiquon Preserve and did not find direct evidence of largemouth bass, bowfin (Amia calva), or spotted gar (Lepisosteus oculatus) preying on common carp. However, it did seem possible from their findings that a diverse assemblage of predatory fishes reduces the number of carp eggs and may induce repression of common carp.

As one of the major tributaries to the Mississippi River, the Illinois River is part of the world-renowned waterfowl migration routes through the Mississippi River flyway. Hagy et al. (2016a) documented the 
tremendous response of waterbirds to wetland restoration at Emiquon showing that about $30 \%$ of all waterbird use-days observed during autumn migration in the Illinois River valley between 2007 and 2013 occurred at Emiquon, even though the Preserve only represented about $5 \%$ of the flooded area in the valley. Among the most noteworthy responses at Emiquon were the American coots, northern pintail (Anas acuta), and green-winged teal (Anas carolinensis), which exhibited the greatest use recorded for any site in the Illinois River Valley since 1948. In a second study by Hagy et al. (2016b), the distribution and behavior of migratory waterbirds across a gradient of disturbance was measured to evaluate the efficacy of spatial and temporal sanctuaries. For the taxa evaluated, zones of exclusion of waterbirds near human disturbances were the smallest in areas least frequently visited by hunters and other users, and exclusion zones were larger in areas most frequently visited. Nonetheless, the investigators questioned the effectiveness of short-term temporal sanctuaries compared to spatial sanctuaries, contending that even few and infrequent disturbances substantially reduce sanctuary conditions, and that continual immigration of migratory birds through the area resulted in naive responses, reducing the potential benefits of temporal sanctuaries.

\section{Ecosystem-level papers}

All the studies provided here fit into the greater system; however, some studies focused on ecosystem processes. Chen et al. (2017) considered that whereas wetland conversion to cropland causes significant release of soil organic matter to atmospheric carbon dioxide, wetland restoration may sequester vast quantities of carbon. They determined that the top $40 \mathrm{~cm}$ of soil held $88 \%$ of carbon storage and $97 \%$ of total nitrogen storage as organic matter. Chen et al. (2017) make a compelling case for comparing soil organic carbon to other key ecological attributes and indicators being monitored, and for establishing storage of soil organic carbon as an indicator of restoration success.

Lemke et al. (2017c) took the opportunity provided by record flooding on the Illinois River in 2013 to study post-flood effects on the Emiquon Preserve and the Merwin Preserve, a Conservancy holding along the Illinois River that was under restoration a decade before Emiquon. While connection of the river flood pulse to the floodplain is understood to be among the most important factors defining the river system, the design, operation, costs, and benefits of the river-tofloodplain connection in the twenty-first century are not clear cut. Concerns about the effectiveness of the managed reconnection between the Emiquon Preserve and the Illinois River center around unnatural sediment and nutrient loading, influx of agro-chemicals, and invasive species. The investigators monitored the short-term effects of these minor (Emiquon) and major (Merwin) flood disturbances on water quality, bacteria, zooplankton, plants, fishes, and birds and found that major flooding markedly changed the microbial and invertebrate communities at the Merwin Preserve, while few significant changes were identified from minor flooding.

Sparks et al. (2016) considered the Emiquon of today along with the potential to understand restoration in the future. A debate about a managed connection between the Preserve and the Illinois River began soon after the Conservancy announced the acquisition in 2000 and continued until construction began in 2015. There is consensus among contributed papers to this Special Issue that some drawdown capability is needed to manage and reduce water levels within Emiquon Preserve to protect and maintain infrastructure and encourage aquatic vegetation. At the heart of the debate is whether river water carrying sediment, contaminants, nutrients, and invasive species will contribute to unacceptable degradation of the wetland. The water management system, completed in 2016, is a gated structure with pumping capacity that can accommodate fish barriers and sampling devices (Fig. 5A, B). Ultimately, the infrastructure is intended to support both scientific research that benefits other projects as well as adaptive management of the Emiquon Preserve (Sparks, 1995; Reuter et al., 2005; King et al., 2010).

Human societies worldwide have altered large rivers and their floodplains for survival (Welcomme, 1985; Bayley, 1995) often with the consequence of greatly diminishing the same ecological processes that have made these systems valuable to societies for millennia (Dynesius \& Nilsson, 1994; Sparks, 1995; Tockner \& Stanford, 2002). Thus, large-scale projects are being undertaken in many parts of the world to recover natural services while also maintaining commercial uses such as navigation and water supply (Bernhardt et al., 2007; Lamouroux et al., 2015). Studies of the Emiquon Preserve as part of the Illinois 
River system make a significant contribution to understanding large river floodplain restoration in the central United States region, and have implications for restoration in critically threatened river ecosystems throughout the world.

Acknowledgements We thank The Nature Conservancy's S. McClure and S. Hagen for assistance with figures, and J. Beverlin and C. Smith for visitor use information. The major research partners at Emiquon include the Illinois Natural History Survey's Forbes Biological Station and Illinois River Biological Field Station and the University of Illinois Springfield. We also thank M. Wiant of the Illinois State Museum for contributing insights on the human ecology at Emiquon. We gratefully acknowledge the important roles of the Natural Resources Conservation Service, Illinois Department of Natural Resources, U.S. Army Corps of Engineers, and US Fish and Wildlife Service in planning, restoring, and managing the Emiquon Preserve.

Open Access This article is distributed under the terms of the Creative Commons Attribution 4.0 International License (http:// creativecommons.org/licenses/by/4.0/), which permits unrestricted use, distribution, and reproduction in any medium, provided you give appropriate credit to the original author(s) and the source, provide a link to the Creative Commons license, and indicate if changes were made.

\section{References}

Angel, J., 2010. Fourth Wettest Year on Record. Illinois State Water Survey. http://www.sws.uiuc.edu/atmos/statecli/ events2009.htm

Baker, F. C., 1906. A catalogue of the Mollusca of Illinois. Bulletin of the Illinois State Laboratory of Natural History 7(6): 53-136.

Bayley, P. G., 1991. The flood pulse advantage and the restoration of river-floodplain systems. Regulated Rivers Research \& Management 6: 75-86.

Bayley, P. B., 1995. Understanding large river: floodplain ecosystems. BioScience 45(3): 153-158.

Bellrose, F. C., F. L. Paveglio, Jr. \& D. W. Steffeck, 1979. Waterfowl populations and the changing environment of the Illinois River valley. Illinois Natural History Survey Bulletin 32:1.

Bellrose, F. C., S. P. Havera, F. L. Paveglio, Jr. \& D. W. Steffeck, 1983. The fate of lakes in the Illinois River Valley. Illinois Natural History Survey Biological Notes 119.

Bernhardt, E. S., E. B. Sudduth, M. A. Palmer, J. D. Allan, J. L. Meyer, G. Alexander, J. Follstad-Shah, B. Hassett, R. Jenkinson, R. Lave, J. McFall \& L. Pagano, 2007. Restoring rivers one reach at a time: Results from a survey of U.S. river restoration practitioners. Restoration Ecology. 15: 482-493.

Bhowmik, N. G. \& M. Demissie, 1989. Sedimentation in the Illinois River valley and backwater lakes. Journal of Hydrology 105: 187-195.
Bowyer, M. W., J. D. Stafford, A. P. Yetter, C. S. Hine, M. M. Horath \& S. P. Havera, 2005. Moist-soil plant seed production for waterfowl at Chautauqua National Wildlife Refuge, Illinois. The American Midland Naturalist 154: 331-341.

Buck, S.J., 1967. Illinois in 1818, by Solon J. Buck. Revised and Reprinted on the Occasion of the Sesquicentennial of the State of Illinois; with an Introduction by Allan Nevins. University of Illinois Press, 1967.

Cain, L. P., 1978. Sanitation Strategy for a Lakefront Metropolis. Northern Illinois University Press, DeKa1b, IL.

Calkins, W. W., 1874. The land \& fresh water shells of La Salle County, Illinois. Ottawa Academy of Natural Sciences Proceedings. 48 p.

Changnon, S. A. \& J. M. Changnon, 1996. History of the Chicago diversion and future implications. Journal of Great Lakes Research 22: 100-118.

Chen, H., S. Popovich, A. B. McEuen \& B. J. Briddell, 2017. Carbon and nitrogen storage of a restored wetland at Illinois' Emiquon preserve: potential for carbon sequestration. Hydrobiologia. doi:10.1007/s10750-017-3218-z.

Choi, Y. D., V. M. Temperton, E. B. Allen, A. P. Grootjans, M. Halassy, et al., 2008. Ecological restoration for future sustainability in a changing environment. Ecoscience 15: 53-64.

Cocker, R. A., 2001. Stephen Forbes and the Rise of American Ecology. Smithsonian Institution Press, Washington D.C: 232.

Craig, W., 1889. On the fishes of the Illinois River system at Havana, Illinois. MS Thesis. University of Illinois, Urbana.

Demissie, M., L. Keefer \& R. Xia, 1992. Erosion and sedimentation in the Illinois River Basin. Illinois Department of Energy and Natural Resources, ILENR/RE-WR-92/04. Springfield, IL.

Demissie, M., A. Wehrmann, Y. Lian, G. Amenu, S. Burch, \& W. Bogner, 2005. Hydrologic and hydraulic considerations for the ecological restoration of the Emiquon along the Illinois River. Proceedings World Water \& Environmental Resources Congress, May 15-19, 2005, Anchorage, AK. American Society of Civil Engineers, Reston, VA

Dynesius, M. \& N. Nilsson, 1994. Fragmentation and flow regulation of river systems in the northern third of the world. Science 266: 753-762.

Esarey, D., 1993 (revised 1995). The origin and early history of Emiquon. Dickson Mounds Museum, Lewistown, IL.

Forbes, S. A., 1876. List of Illinois crustacea, with descriptions of new species. Illinois Natural History Survey Bulletin 1: $3-25$.

Forbes, S. A., 1887. The Lake as a Microcosm. Bulletin of the Peoria Scientific Association 1887: 77-87.

Forbes, S. A., 1888. On the food relations of fresh-water fishes: a summary and discussion. Illinois Natural History Survey Bulletin 2: 475-538.

Forbes, S. A., 1907. On the local distribution of certain Illinois fishes: an essay in statistical ecology. Illinois Natural History Survey Bulletin 7: 273-303.

Forbes, S. A. \& R. E. Richardson, 1908. Fishes of Illinois. Illinois Printing Company, Danville, IL. 
Forbes, S. A. \& R. E. Richardson, 1913. Studies on the biology of the upper Illinois River. Bulletin of the Illinois State Laboratory of Natural History 9: 481-574.

Forbes, S. A. \& R. E. Richardson, 1919. Some recent changes in Illinois River biology. Illinois Natural History Survey Bulletin 9: 481-574.

Guida, R. J., J. W. F. Remo \& S. Secchi, 2016. Tradeoffs of strategically reconnecting rivers to their floodplains: the case of the Lower Illinois River. Science of the Total Environment 572: 43-55.

Hagy, H. M., C. Hine, M. Horath, A. Yetter, R. Smith \& J. Stafford, 2016a. Waterbirds as indicators of floodplain restoration. Hydrobiologia. doi:10.1007/s10750-0163004-3.

Hagy, H. M., M. M. Horath, A. P. Yetter, C. S. Hine \& R. V. Smith, 2016b. Evaluating tradeoffs between sanctuary for migrating waterbirds and recreational opportunities in a restored wetland complex. Hydrobiologia. doi:10.1007/ s10750-016-2711-0.

Hart, C. A., 1896. On the entomology of the Illinois River and adjacent waters. Bulletin of the Illinois State Laboratory of Natural History 4(6): 1-273.

Havera, S. P., \& K. E. Roat, 2003. Forbes Biological Station: the past and the promise. Illinois Natural History Survey Special Publication 10

Havera, S. P., K. E. Roat \& L. L. Anderson, 2003. The Thompson Lake/Emiquon Story. Illinois Natural History Survey Special Publication 25, Champaign, IL.

Hempel, A., 1898. A list of the protozoa and Rotifera found in the Illinois River and adjacent lakes at Havana, Illinois. Bulletin of the Illinois State Laboratory of Natural History 5(6): 301-388.

Hill, L., 2000. The Chicago River: A Natural and Unnatural History. Lake Claremont Press, Chicago, IL.

Hine, C.S., H.M. Hagy, A.P. Yetter, M.M. Horath, 2014. Waterbird and wetland monitoring at the Emiquon Preserve: annual report 2013. Illinois Natural History Survey Technical Report (18).

Hine, C. S., H. M. Hagy, M. M. Horath, A. P. Yetter, R. V. Smith \& J. D. Stafford, 2016. Response of aquatic vegetation communities and other wetland cover types to floodplain restoration at Emiquon Preserve. Hydrobiologia. doi:10. 1007/s10750-016-2893-5.

Hobbs, R. J. \& V. A. Cramer, 2008. Restoration ecology: Interventionist approaches for restoring and maintaining ecosystem function in the face of rapid environmental change. Annual Review of Environment and Resources 33: 39-61.

Illinois River Strategy Team, 1997. Integrated management plan for the Illinois River Watershed. Technical report of the Illinois River Strategy Team. State of Illinois.

Jackson, C. R. \& C. M. Pringle, 2010. Ecological benefits of reduced hydrologic connectivity in intensively developed landscapes. BioScience 60(1): 37-46.

Jenkins, Merchant \& Nankivil and W.B Walraven. 1950. Survey and report on potential conservation areas along the Illinois River from Hennepin to Grafton. Illinois Department of Conservation, State of Illinois

Jha, M., Z. Pan, E. S. Takle \& R. Gu, 2004. Impacts of climate change on streamflow in the Upper Mississippi River
Basin: a regional climate model perspective. J. Geophys. Res. 109: D09105.

Junk, W. J., P. B. Bayley and R. E. Sparks. 1989. The flood pulse concept in river-floodplain systems. In Proceedings of the International Large River Symposium, 106: 110-127. Canadian Special Publication of Fisheries and Aquatic Sciences.

King, A. J., K. A. Ward, P. O'Connor, D. Green, Z. Tonkin \& J. Mahoney, 2010. Adaptive management of an environmental watering event to enhance native fish spawning and recruitment. Freshwater Biology 55: 17-31.

Kofoid, C. A., 1903. The plankton of the Illinois River, 1894-1899, with introductory notes upon the hydrography of the Illinois River and its basin. Part I. Quantitative investigations and general results. Bulletin of the Illinois State Laboratory of Natural History 6(2): 95-629.

Kofoid, C. A., 1908. The plankton of the Illinois River, 1894-1899, with introductory notes upon the hydrography of the Illinois River and its basin. Part II. Constituent organisms and their seasonal distribution. Bulletin of the Illinois Laboratory of Natural History 8(1): 1-361.

Kunkel, K. E., L. E. Stevens, S. E. Stevens, L. Sun, E. Janssen, D. Wuebbles, S. D. Hilber, M. S. Timlin, L. Stoecker, N. E. Westcott, and J. G. Dobson. 2013. Regional climate trends and scenarios for the U.S. National Climate Assessment. Part 3. Climate of the Midwest. U.S. NOAA Technical Report NESDIS 142-3.

Lamouroux, N., J. A. Gore, F. Lepori \& B. Statzner, 2015. The ecological restoration of large rivers needs science-based, predictive tools meeting public expectations: an overview of the Rhône project. Freshwater Biology 60: 1069-1084.

Lemke, A. M., T. T. Lindenbaum, W. L. Perry, M. E. Herbert, T. H. Tear \& J. R. Herkert, 2010. Effects of outreach on the awareness and adoption of conservation practices by farmers in two agricultural watersheds of the Mackinaw River, Illinois. Journal of Soil and Water Conservation 65: 304-315.

Lemke, A. M., K. G. Kirkham, T. T. Lindenbaum, M. E. Herbert, T. H. Tear, W. L. Perry \& J. R. Herkert, 2011. Evaluating agricultural best management practices in tiledrained subwatersheds of the Mackinaw River, Illinois. Journal of Environmental Quality 40: 1215-1228.

Lemke, A. M., J. R. Herkert, J. W. Walk \& K. D. Blodgett, 2017a. Application of Key Ecological Attributes to assess early restoration of river floodplain habitats: A case study. Hydrobiologia. doi:10.1007/s10750-017-3261-9.

Lemke, M. J., H. M. Hagy, A. F. Casper and H. Chen, 2017b. Chapter 5. Floodplain Wetland Restoration along the Illinois River. In: Lenhart, C. and P. C. Smiley Jr. (eds). Ecological Restoration in the Midwest: Building on the Legacy.

Lemke, M. J., S. F. Paver, K. Dungey, L. F. M. Velho, A. Kent, L. C. Rodrigues, D. M. Kellerhals \& M. Randle, 2017c. Diversity and succession of pelagic microorganism communities in a newly restored Illinois River floodplain lake. Hydrobiologia. doi:10.1007/s10750-017-3327-8.

Lemke, M. J., H. M. Hagy, K. E. Dungey, A. F. Casper, A. M. Lemke, T. D. VanMiddlesworth \& A. Kent, 2017d. Echoes of a flood pulse: Short-term effects of record flooding of the Illinois River on floodplain lakes under 
restoration. Hydrobiologia. doi:10.1007/s10750-0173220-5.

Lerczak, T.V., and R.E. Sparks, 1995. Fish populations in the Illinois River. Pages 239-241 in National Biological Service National Status and Trends Report. U.S. Government Printing Office, Washington, D.C.

Lian, Y., J. K. You, R. E. Sparks \& M. Demissie, 2012. Impact of human activities to hydrologic alterations on the Illinois River. Journal of Hydrologic Engineering. doi:10.1061/ (ASCE)HE.1943-5584.0000465.

Matthews, J. W. \& G. Spyreas, 2010. Convergence and divergence in plant community trajectories as a framework for monitoring wetland restoration progress. Journal of Applied Ecology 47: 1128-1136.

McClelland, M. A., G. G. Sass, T. R. Cook, K. S. Irons, N. N. Michaels, T. M. O'Hara \& C. S. Smith, 2012. The longterm Illinois River fish population monitoring program. Fisheries. 37(8): 340-350. doi:10.1080/03632415.2012. 704815.

Mills, H. B., W. C. Starrett \& F. C. Bellrose, 1966. Man's effect on the fish and wildlife of the Illinois River. Illinois Natural History Survey Biological Notes 57: 1-24.

National Research Council, 1992. Restoration of aquatic ecosystems: Science, technology, and public policy. National Academy Press, Washington, D.C.: 552.

Parrish, J. D., D. P. Braun \& R. S. Unnasch, 2003. Are we conserving what we say we are? Measuring ecological integrity within protected areas. BioScience 53: 851-860.

Pegg, M. A. \& M. A. McClelland, 2004. Spatial and temporal patterns in fish communities along the Illinois River. Ecology of Freshwater Fish 13: 125-135.

Ramsar, 2014. The list of wetlands of international importance. http://ramsar.rgis.ch/pdf/sitelist.pdf

Real, L. A. \& J. H. Brown, 1991. Foundations of ecology: Classic papers with commentaries. University of Chicago Press, Chicago, IL.

Reuter, M., K. Lubinski, P. West, D. Blodgett \& M. Khoury, 2005. The Nature Conservancy's approach to conserving and rehabilitating biological diversity in the Upper Mississippi River system. Large Rivers 15: 549-560.

Richardson, R. E., 1928. The bottom fauna of the middle Illinois River, 1913-1925; its distribution, abundance, valuation, and index valve in the study of stream pollution. Illinois Natural History Survey Bulletin 17(12): 387-475.

Scarpino, P.V., 1985. Great River: an environmental history of the upper Mississippi, 1890-1950. University of Missouri Press.

Schneider, D. W., 2000. Local Knowledge, Environmental Politics, and the Founding of Ecology in the United States: Stephen Forbes and "The Lake as a Microcosm" (1887). Isis. 91:681-705

Sietman, B. E., S. D. Whitney, D. E. Kelner, K. D. Blodgett \& H. L. Dunn, 2001. Post-extirpation recovery of the freshwater mussel (Bivalvia: Unionidae) fauna in the upper Illinois River. Journal of Freshwater Ecology 16(2): 273-281.

Sparks, R. E., 1995. Need for ecological management of large rivers and their floodplains. BioScience 45(3): 168-182.

Sparks, R. E., P. B. Bayley, S. L. Kohler \& L. L. Osborne, 1990. Disturbance and recovery of large floodplain rivers. Environmental Management 14(5): 699-709.
Sparks, R. E., P. E. Ross, \& F. S. Dillon, 1993. Identification of toxic substances in the upper Illinois River. Final Report. Illinois Department of Energy and Natural Resources, Springfield, IL

Sparks, R. E., K. D. Blodgett, A. F. Casper, H. M. Hagy, M. J. Lemke, L. F. M. Velho, \& L. C. Rodrigues, 2016. Why experiment with success? Opportunities and risks in applying assessment and adaptive management to the Emiquon floodplain restoration project. Hydrobiologia. doi: 10.1007/s10750-016-2785-8.

Stafford, J. D., M. M. Horath, A. P. Yetter, R. V. Smith, and C. S. Hine, 2010. Historical and contemporary characteristics and waterfowl use of Illinois River valley wetlands. Wetlands 30(3): 565-576.

Starrett, W. C., 1971. A Survey of the mussels (Unioncea) of the Illinois River: a polluted stream. Illinois Natural History Survey Bulletin 30: 265-403.

Starrett, W. C., 1972. Man and the Illinois River. Pages 131-167. In R. T. Oglesby, C. A. Carlson, and J. A. McCann, editors. River ecology and Man. Academic Press, New York.

Suding, K. N., 2011. Toward an era of restoration in ecology: successes, failures, and opportunities ahead. Annual Review of Ecology, Evolution, and Systematics 42: 465-487.

Suding, K. N., K. L. Gross \& G. Houseman, 2004. Alternative states and positive feedbacks in restoration ecology. Trends in Ecology and Evolution 193: 46-53.

The Nature Conservancy (TNC), 1998. Illinois River Site Conservation Plan. The Nature Conservancy of Illinois, Peoria, IL.

The Nature Conservancy (TNC), 2000. The past and future of the Illinois River Valley: Emiquon, the opportunity of a lifetime. Prepared by the Great Rivers Area staff of The Nature Conservancy for the Emiquon Science Advisory Council. Peoria, IL

The Nature Conservancy, 2006. Key Attributes and Indicators for Illinois River Conservation Targets at The Nature Conservancy's Emiquon Preserve. The Nature Conservancy, Peoria, Illinois. www.uis.edu/emiquon/wp-content/ uploads/sites/78/2013/04/KEA_Report_and_Analysis.pdf. Accessed November 7, 2015.

Thompson, D. H., 1928. The "knothead" carp of the Illinois River. Illinois Natural History Survey Bulletin 17(8): 285-320.

Thompson, J., 2002. Wetlands drainage, river modification, and sectoral conflict in the lower Illinois valley, 1890-1930. Southern Illinois University Press, Carbondale.

Tockner, K. \& J. A. Stanford, 2002. Riverine flood plains: present state and future trends. Environmental Conservation 29: 308-330.

Tomer, M. D. \& K. E. Schilling, 2009. A simple approach to distinguish land-use and climate-change effects on watershed hydrology. Journal of Hydrology 376(2009): 24-33.

Upper Mississippi River Conservation Committee, 2000. A river that works and a working river. Upper Mississippi River Conservation Committee.

USACE (U.S. Army Corps of Engineers), 2006. Illinois River Basin restoration comprehensive plan. U.S. Army Corps of Engineers, Rock Island District, Rock Island, Illinois. 
USACE (U.S. Army Corps of Engineers), 2016. Report to congress Upper Mississippi River restoration program. U.S. Army Corps of Engineers, Rock Island District, Rock Island, Illinois.

van der Valk, A. G. \& C. B. Davis, 1978. The role of seed banks in the vegetation dynamics of prairie glacial marshes. Ecology 59: 322-335.

VanMiddlesworth, T. D., N. N. Michaels \& A.F. Casper, 2014. The Nature Conservancy's Emiquon Preserve Fish and Aquatic Vegetation Monitoring 6-year (2007-2012) Report. INHS Technical Report (01).

VanMiddlesworth, T. D., N. N. McClelland, G. G. Sass, A. F. Casper, T. W. Spier \& M. J. Lemke, 2016a. Fish community succession and biomanipulation to control two common aquatic ecosystem stressors during a large-scale floodplain lake restoration. Hydrobiologia. doi:10.1007/ s10750-016-2696-8.

VanMiddlesworth, T. D., G. G. Sass, B. A. Ray, T. W. Spier, J. D. Lyons, N. N. McClelland \& A. F. Casper, 2016b. Food habits and relative abundances of native piscivores: implications for controlling common carp. Hydrobiologia. doi:10.1007/s10750-016-2866-8.

Welcomme, R. L., 1985. River fisheries. FAO Fisheries Technical Paper 262: 1-330.

Wiant, M. D., \& A. Berkson, 2004. The Archaic Period. In Wiant, M. D. \& A. Berkson (eds), Discover Illinois Archaeology. Illinois Association for Advancement of Archaeology and the Illinois State Archaeological Survey, Champaign, Illinois: 6-7. 